\title{
Cytokines, Lipid Peroxide and Nitric Oxide in Egyptian Hepatocellular Carcinoma on Top of HCV and HBV Infection
}

\author{
Osman E.E., Mabrouk F.M., Hassan H.A., Aboelyazed S.M., \\ sINT Medicine (Girls) - AL AZHAR University \\ Salem T.H. Biochemistry - ASSUIT University \\ Ahmed G.O. Clinical Pathology Dept. AL AZHAR University \\ Hassan A.A. Pathology - AL AZHAR University
}

\begin{abstract}
:
Background and Aims: Many studies have shown the relative roles of hepatitis B and C viruses in hepato-carcinogenesis. The aim of this study is to define the independent and interactive roles of some cytokines namely, TNF $\alpha$, IL-6, IL- $1 \beta$ together with NO and TEARS in the genesis of HCC following the infection with such viruses.

Patients and methods: Blood samples were taken from 58 patients with hepatocellular carcinoma and were divided into four groups: a) 28 patients with $\mathrm{HCV}$, b) 10 patients with $\mathrm{HBV}$, c) 11 patients with $\mathrm{B}+\mathrm{C}$, d) 9 patients without viral infection. In addition, 20 healthy subjects served as control group for each, TNF $\alpha$, IL-6, and IL-1 $\beta$ were measured using ELISA technique, in addition to NO and TBARs using chemical methods.

Results: Patients with coinfection B-C viral infection showed the highest levels in studied parameters. Patients with HCV and HBV separately showed more or less similar results. However, patients without viral infection showed the least higher levels comparing to the control group.

Conclusion: Cytokines in addition to NO and TEARS have a definite role in hepatic carcinogenesis. Coinfection with the two viruses carries a synergistic risk factor of hepatocellular carcinoma development. Depending on the results of the studied parameters HCV did not show predominancy on HBV. Further studies are needed to clarify the exact mechanism of carcinogenesis especially in HCV patients.
\end{abstract}

Key Words: HCC, HCV, HBV, IL- $1 \beta$, IL-16 TNF $\alpha$, NO. TBARs

\section{Introduction}

Hepatocellular carcinoma (HCC) is one of the most frequent malignant tumours in developing countries (Laurent Purg et al., 2001), HCC risk factors, such as infection by hepatitis B or C viruses (HBV and $\mathrm{HCV}$ ), cirrhosis of various etiology, primary hemo chromatosis, and prolonged exposure to Afatoxin BI, are well proven (Kato, 2001). However, the carcinogensis mechanisms are still poorly understood and seem to differ according to the risk factor involved (Arbuthnot and Kew, 2001) and (Umeda and Hino, 2002). Epidemiological and experimental evidences have established that chronic infection with hepatitis B virus (HBV) and hepatitis C virus (HCV) are the major risk factors for hepatocellular carcinomas (HCC) in humans (Kew et al., 1997, Kondo et al, 2001). The epidemiological studies also indicate that the relative role of these two viruses in hepatocellular carcinogenesis vary considerably among different populations. Coinfection with the two viruses carries a synergistic risk of hepatocellular carcinoma formation.

Cytokines are synthesized and secreted in the liver mostly by kupffer cells and play a key role in inflammatory processes and immunological responses related to liver diseases, which are initiated by hepatocytes damage (Flisiak, 1999). Peter et al. (2000) emphasized a central role for interleukin 6 (IL-6) and soluble interleukin 6 receptor (sIL-6R) in liver regeneration. They added that, a possible 
therapeutic potential for the designer cytokine type IL-6 in clinical situations associated with liver regeneration. However, Liorent et al. (1996) reported high degree of cytokine gene expressions namely transforming growth factor one beta (TGRFIB), interleukin one beta (IL-1 $\beta$ ) and Interleukins 2, 6, 8 and 10 as well as tumour necrosis factor alpha, in post hepatitis $\mathrm{C}$ liver cirrhosis. The authors concluded that these cytokines appear to participate in the pathogenesis of the mild to severe liver damage and liver carcinogenesis.

Cellular oxidative respiration results in the generation of a number of reactive oxygen species (ROS) including super oxide $\left(\mathrm{O}_{2}\right)$ hydroxyl radical $\left(\mathrm{OH}^{\prime \prime}\right)$ and other free radicals that rapidly dismutase to form $\mathrm{H}_{2} \mathrm{O}_{2}$. Accumulations of ROS contribute to cell injury through effects on gene and protein expression, DNA damage and lipid peroxidation. (Schlenker et al, 2000). In this regard, hepatocyte expression of inducible nitric oxide synthase (iNOS) and synthesis of nitric oxide (NO) posses protective anti oxidant functions in models reperfusion injury (Kuo et al., 2000). This effect is independent of both the oxidant species and the specific proinflammatory roles of cytokine that characterize these pathophysiological states. However, Kuo et al. (2000) reported that super oxide enhances interleukin-1 $\beta$ and mediate CI transcription of the hepatocyte-inducible nitric oxide synthase gene.

Moreover IL-1 $\beta$ followed by TNF$\alpha$ and IL-6, and other cytokines were the most effective cytokines to induce $\mathrm{MN}^{2+}$ superoxide dismutase activity in human hepatoma cells (Pontisso et al., 1998).

It is concluded from the pervious short review that IL- $\beta \beta$, IL-6 and TNF$\alpha$ together with oxygen species mainly in the form of lipid peroxide and nitric oxide, are very dynamic effectors of the normal and the pathological behavior of the liver cells. Moreover, these effects are modulated in the complicated situation with infection by HCV or HBV. Therefore, investigating the nature of the expression of these proinflammatory effectors at protein level in addition to the oxidant/antioxidant mechanism in the blood of patients with hepatocellular carcinoma with or without viral infection could elucidate their role in protection and/or pathogenetic causation of this complicated condition.

\section{Aim of the Study:}

1. To investigate the role of three cytokines namely TNF- $\alpha$, IL- $1 \beta$ and IL-6 together with lipid peroxide and nitric oxide in cases of hepatocellular carcinoma with or without previous viral infection among Egyptian patients.

2. To highlight the effect of bilharzial infection on hepatic carcinogensis.

3. To find any relation between the previous parameters and the type of viral infection.

4. To report any correlation between these parameters.

5. To find a correlation between these parameters and the grading of the hepatocellular carcinoma.

6. To correlate these parameters with the liver functions and its enzymatic status.

7. To discover a new regimen for using such cytokines as follow up parameters and determining a possible role for using anticytokines in the treatment of hepatocellular carcinoma.

\section{Material and Methods}

\section{The present study include 58 subjects divided into the following groups:}

Group 1: included 28 patients (26 males and 2 females) suffering from hepatitis $\mathrm{C}$ virus infection with hepatocellular carcinoma. Their ages ranged from 33-70 years with mean \pm SD of $(52-5+10.6)$ out of the 28,14 patients had a past history of Bilharziasis.

Group 2: included 10 patients (all are males) with hepatocellular carcinoma and hepatitis B virus infection. Their ages ranged from 31-68 years with mean \pm SD of (52.8 \pm 9.2$)$ Two out of the 11 patients had past history of Bilharziasis, and three had history of previous operations.

Group 3: included 11 patients (all males were diagnosed with hepatocellular carcinoma and co-infection by both virus B and $C$. their ages ranged from (28-71) years with mean $\pm S D$ is $(47.3+11.3)$ Five out of 
them had past history of Bilharziasis and three had history of blood transfusion.

Group 4: included 9 patients (all were males) with hepatocellular carcinoma without co-infection with viral infection, but two of them had past history of Biharziasis. Their ages ranged from 50-78 with mean \pm SD of $(58.5 \pm 13.1)$

The patients were recruited among the:

1.Attendants of internal medicine department Al-Zahraa University Hospital (AlAzhar University).

2. Attendants of Tropical medicine department, El-Minia University Hospital and El-Minia Institute of Oncology.

3. Attendants of Internal medicine department, Assiut University Hospital and Assiut Institute of Oncology.

4. Attendants of Internal medicine department, Sohage University Hospital.

Smokers in addition to Patients with diabetes mellitus, heart failure, hypertension, renal failure, Cancer, and Fever were excluded from this study.

Group 5: Included 20 healthy nonsmoker male subjects, their ages and socioeconomic status matched with the previous groups, serving as a control group.

For all patients and healthy subjects the following parameters were done:

1. Full history and thorough clinical examination.

2. Chest X-ray.

3. Abdominal ultrasonography.

4. Routine liver function tests including, total bilirubin, total protein albumin, liver enzymes: Alanine amino transferase, (ALT), and alkaline phosphatase, in addition to prothrombin time and concentration.

5. Antigens and antibodies for hepatitis $B$ virus (HBV) and hepatitis $\mathrm{C}$ virus antibodies (HCVJ by ELISA technique.).

6. HCV / RNA detection by polymerase chain reaction, (PCR).

7. Liver biopsy was carried out only on patients with HCC provided that the prothrombin time and concentrations are favourable. The grading was carried out according to Comparing the cytokines among patients with different grades of HCC was only carried out in the group of $\mathrm{HCC}$ on top of $\mathrm{HCV}$ as this group comprised the highest number of patients allowing statistical comparison of results.

8. Five-millmeter blood had been taken from each patient and control subject under complete aseptic conditions using suction tubes. Sera had been separated and deeply frozen until the time of usage to estimate the following:

i. Tumour Necrosis factor-Alpha (TNF- $\alpha$ ). By ELISA technique.

ii. Interleukin-one Beta (IL-1 $\beta$ ). By ELISA technique.

iii. Interleukin six (IL-6). By ELISA technique.

iv. Alpha fetoprotein ( $\alpha$-FP). By ELISA technique.

v. Lipid peroxide (LPS) in the form of TEARS MDA equivalents. By Satoh (1978).

vi. Nitric oxide (NO). By Van Bezooijeen et al, (1998).

\section{Results}

The pathological study of liver biopsies of 28 patients suffering from hepatocelluler carcinoma with HCV coinfection revealed that 15 are grade 11 and 13 are grade III.

Symptoms and signs of Egyptian HCC patients are shown in table (1). Table (2) shows risk factors of HCC patients.

Patients with HCC and both B and C viral co-infection recorded the highest serum level of TNF $\alpha$ compared to the other four groups $(\mathrm{p}<0.001$, while no statistical difference was recorded between HCC with $\mathrm{B}$ infection and $\mathrm{HCC}$ with $\mathrm{C}$ infection (the two pathological grades). On the other hand patients with HCC without viral infection recorded the least level, but still statistically higher than control $\mathrm{p}<0.001$ (table 3).

IL-6 was the highest in the sera of HCC $\mathrm{B}+\mathrm{C}$ patients $\mathrm{P}<0.001$ compared to all groups. HCC-C patients showed significant increased levels compared to HCC-B patients $(\mathrm{p}<0.01)$ Patients with HCC non-B non-C showed the least levels, but still higher compared to the control $\mathrm{p}<0.001$ (Table 3).

Serum level of IL-1 $\beta$ was significantly higher in patients with HCC$\mathrm{B}+\mathrm{C}$ compared to all studied groups 
$\mathrm{p}<0.001$. No significant difference was recorded between patients with $\mathrm{HCC}-\mathrm{B}$ and $\mathrm{HCC}-\mathrm{C}$, while patients with $\mathrm{HCC}$ non-B non-C recorded the least levels, but still higher than control $\mathrm{p}<0.01$ (Table 3 ).

Serum levels of TEARS, MDA equivalent and $\mathrm{NO}$ showed the highest levels in patients with $\mathrm{HCC} \mathrm{B}+\mathrm{C}$ compared to all studied groups $(\mathrm{p}<0.001)$ patients with HCC-B showed no significant difference compared to HCC-C patients (table 3).

On the other hand, no significant difference was recorded in $\mathrm{HCC}-\mathrm{C}$ patients with Bilharziasis compared to nonBilharzial patients in all studied parameters (table 4).

Patients with $\mathrm{HCC}$ associated with $\mathrm{HCV}$ infection showed positive correlation between TNF- $\alpha$ and IL-1 $\beta$, IL-6, $\alpha$-FP, serum bilirubin, alkaline phosphatase, NO and tumor grading and between each other, while negative correlation between prothrombin concentration and IL-6, s.bilirubin, alkaline phosphatase, total protein, $\mathrm{NO}$ and tumour grading.

Table (1): Symptoms and signs of all included patients (NO. 58)

\begin{tabular}{|l|c|c|}
\hline \multirow{2}{*}{ Symptoms and signs } & Frequency of + ve cases & Percentage \\
\cline { 2 - 3 } & & NO. \\
\hline Fever & 3 & 5.1 \\
\hline Malaise & 41 & 70.6 \\
\hline Weight loss & 13 & 22.4 \\
\hline Jaundice & 41 & 70.6 \\
\hline Abd. Pain & 58 & 100 \\
\hline Epistaxis & 40 & 68.9 \\
\hline Bleeding gums & 39 & 67.2 \\
\hline Itching & 3 & 5.1 \\
\hline Haematemsis & 16 & 27.5 \\
\hline Melena & 7 & 12.1 \\
\hline Foeter hepaticus & 8 & 13.7 \\
\hline Gynacomastia & 7 & 12.1 \\
\hline Spider navei & 5 & 8.6 \\
\hline Flapping tremors & 8 & 13.7 \\
\hline Palmer erythema & 17 & 29.3 \\
\hline Hepatomegaly & 45 & 77.5 \\
\hline Splenomegaly & 51 & 87.9 \\
\hline Ascites & 42 & 72.4 \\
\hline Oedma L.L & 24 & 41.3 \\
\hline Easy Fatigability & 51 & 88 \\
\hline & & \\
\hline
\end{tabular}

Table (2): Risk factors for all patients (NO. 58)

\begin{tabular}{|l|c|c|}
\hline Risk factors & NO. & Percentage \\
\hline None & 17 & 29.3 \\
\hline Blood transfusion & 8 & 13.7 \\
\hline Surgical op. & 1 & 1.7 \\
\hline Tattooing & 1 & 1.7 \\
\hline Dental proced. & 1 & 1.7 \\
\hline Oral Bilh. Ttt & 3 & 5.1 \\
\hline Iniect Bilh. Ttt & 17 & 29.3 \\
\hline Combined Bilh. $\mathrm{ttt}$ & 4 & 6.8 \\
\hline Smoking & 6 & 10.3 \\
\hline No of cases & 58 & 100 \\
\hline
\end{tabular}

Table (3): Biochemical parameters in all studied groups mean \pm SD. 


\begin{tabular}{|c|c|c|c|c|c|c|c|}
\hline & Control & $\begin{array}{c}\text { HCC/non } \\
\text { BC }\end{array}$ & $\mathrm{HCC} / \mathrm{B}$ & $\mathrm{HCC} / \mathrm{C}$ & HCC/CII & HCC/CIII & $\mathrm{HCC} / \mathrm{BC}$ \\
\hline \multirow[t]{2}{*}{ TNF- pg/m1 } & 6.34 & 30.43 & 53.74 & 66.12 & 43.51 & 68.37 & 154.3 \\
\hline & 0.83 & 4.03 & 8.74 & 3.90 & 3.28 & 5.15 & 31.4 \\
\hline \multirow[t]{2}{*}{ 11-6- pg/ml } & 2.82 & 26.57 & 38.06 & 55.99 & 36.62 & 78.17 & 133.5 \\
\hline & 0.35 & 3.39 & 3.69 & 4.72 & 4.48 & 2.001 & 13.33 \\
\hline \multirow[t]{2}{*}{ IL-1B- $\mathrm{pg} / \mathrm{ml}$} & 5.23 & 34.40 & 55.21 & 58.38 & 43.73 & 75.29 & 204.1 \\
\hline & 0.62 & 3.20 & 6.20 & 3.83 & 2.56 & 4.2 & 23.01 \\
\hline \multirow[t]{2}{*}{ A f.p. $-\mathrm{ng} / \mathrm{ml}$} & 3.35 & 453.8 & 539.4 & 582.4 & 359.9 & 797.5 & 661 \\
\hline & 0.43 & 39.7 & 48.48 & 49.55 & 53.04 & 30.17 & 54.50 \\
\hline \multirow[t]{2}{*}{ T.P. g/dL } & 7.57 & 6.46 & 6.91 & 6.9 & 7.1 & 6.7 & 7.03 \\
\hline & 0.087 & 0.21 & 0.22 & 0.16 & 0.24 & 0.19 & 0.32 \\
\hline \multirow[t]{2}{*}{$\mathrm{A} / \mathrm{b} .-\mathrm{g} / \mathrm{dL}$} & 4.32 & 2.74 & 2.75 & 2.8 & 2.64 & 2.99 & 2.69 \\
\hline & 0.06 & 0.22 & 0.14 & 0.10 & 0.13 & 0.14 & 0.195 \\
\hline \multirow[t]{2}{*}{ Proth. \% } & 94.5 & 68.78 & 64.6 & 66.7 & 74.8 & 57.5 & 56.0 \\
\hline & 0.45 & 4.89 & 4.9 & 2.9 & 4.27 & 1.88 & 2.098 \\
\hline \multirow[t]{2}{*}{ T.Bil. $-\mathrm{mg} / \mathrm{dL}$} & 0.75 & 2.3 & 2.8 & 2.9 & 1.8 & 4.3 & 4.2 \\
\hline & 0.018 & 0.29 & 0.31 & 0.28 & 0.19 & 0.20 & 0.26 \\
\hline \multirow[t]{2}{*}{ SCPT-IU } & 13.6 & 104.8 & 115.5 & 83.82 & 69.0 & 100.9 & 107.9 \\
\hline & 1.09 & 14.5 & 18.09 & 9.93 & 9.93 & 17.3 & 10.44 \\
\hline \multirow[t]{2}{*}{ Al.ph-IU } & 30.74 & 117.3 & 139.0 & 189.1 & 126.6 & 261.3 & 240.5 \\
\hline & 1.15 & 11.9 & 15.97 & 19.9 & 18.86 & 25.24 & 12.98 \\
\hline \multirow[t]{2}{*}{ TBARS- M/L } & 1.79 & 2.72 & 3.27 & 3.08 & 2.87 & 3.29 & 4.86 \\
\hline & 0.09 & 0.32 & 0.27 & 0.25 & 0.29 & 0.41 & 0.27 \\
\hline \multirow[t]{2}{*}{ NO-nM/ml } & 24.28 & 78.17 & 155.7 & 148.6 & 69.03 & 240.4 & 343.5 \\
\hline & 1.43 & 6.29 & 14.91 & 19.29 & 5.42 & 21.29 & 43.65 \\
\hline
\end{tabular}

Table (4) : Comparison between HCC-C associated with Bilharziasis (No.=14) and without Bilharziasis (No.=14) in all parameters studied. $(\mathbf{M} \pm \mathbf{S D})$.

\begin{tabular}{|l|c|c|c|}
\hline & Bilharziasis & Non-Bilharziasis & P-Value \\
\hline TNF-a $(\mathrm{pg} / \mathrm{ml})$ & $59.56+5.369$ & $52.69+5.706$ & 0.3880 \\
\hline $\mathrm{Il}-\mathrm{Ib}(\mathrm{pg} / \mathrm{ml})$ & $58.83+4.855$ & $57.94+6.102$ & 0.9097 \\
\hline $\mathrm{Il}-6(\mathrm{pg} / \mathrm{ml})$ & $63.71+6.061$ & $48.09+60813$ & 0.0987 \\
\hline$\alpha-\mathrm{FP}(\mathrm{ng} / \mathrm{ml})$ & $651.7+55.47$ & $513.1+79.89$ & 0.1659 \\
\hline Prothrombin $(\%)$ & $67.14+3.361$ & $66.43+4.912$ & 0.9054 \\
\hline Albumin $(\mathrm{g} / \mathrm{dl})$ & $2.807+0.1714$ & $2.800+0.1177$ & 0.9729 \\
\hline Total protein $(\mathrm{g} / \mathrm{ml})$ & $6.686+0.2383$ & $7.243+0.1603$ & 0.0633 \\
\hline SGPT $(\mathrm{IU})$ & $87.50+16.64$ & $80.14+11.45$ & 0.7186 \\
\hline Total Bilirubin $(\mathrm{mg} / \mathrm{ml})$ & $3.048+0.4174$ & $2.791+0.3665$ & 0.6473 \\
\hline ALK-Phosphatase $(\mathrm{IU})$ & $177.0+21.11$ & $260.4+60.71$ & 0.2057 \\
\hline NO $(\mathrm{nM} / \mathrm{ml})$ & $32.83+5.277$ & $26.61+5.701$ & 0.4305 \\
\hline TBARS $(\mu$ ML) & $2.466+0.21 .57$ & $3.043+0.3256$ & 0.3256 \\
\hline
\end{tabular}


Cytokines, Lipid Peroxide and Nitric Oxide in Egyptian........

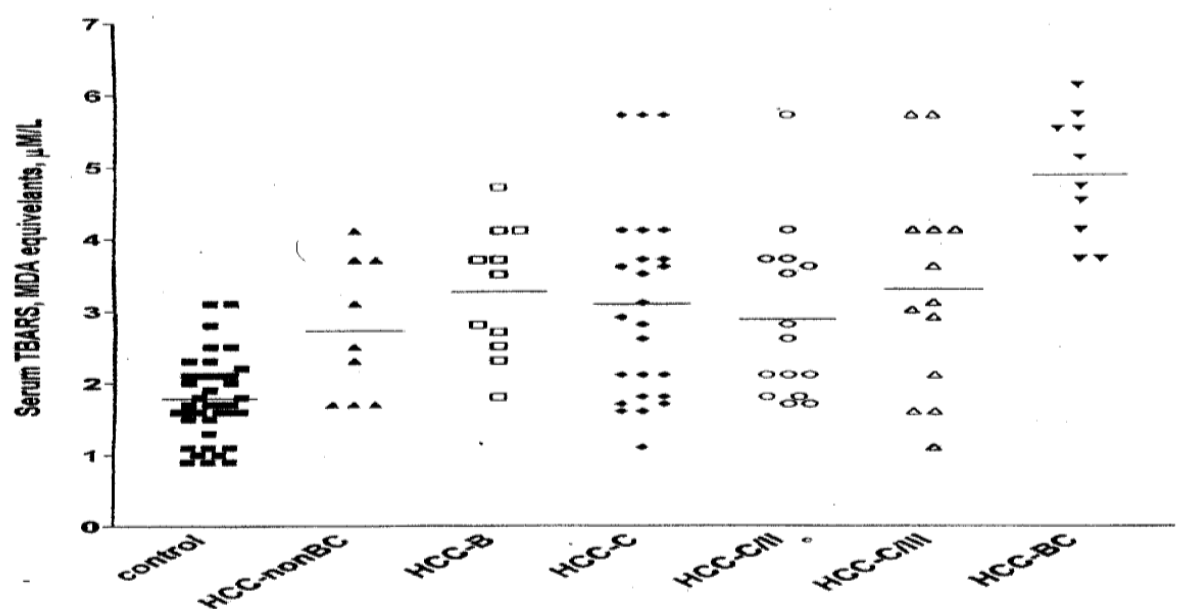

Fig. (1): Scaterogram for the individual data of serum TEARS in all studied groups.

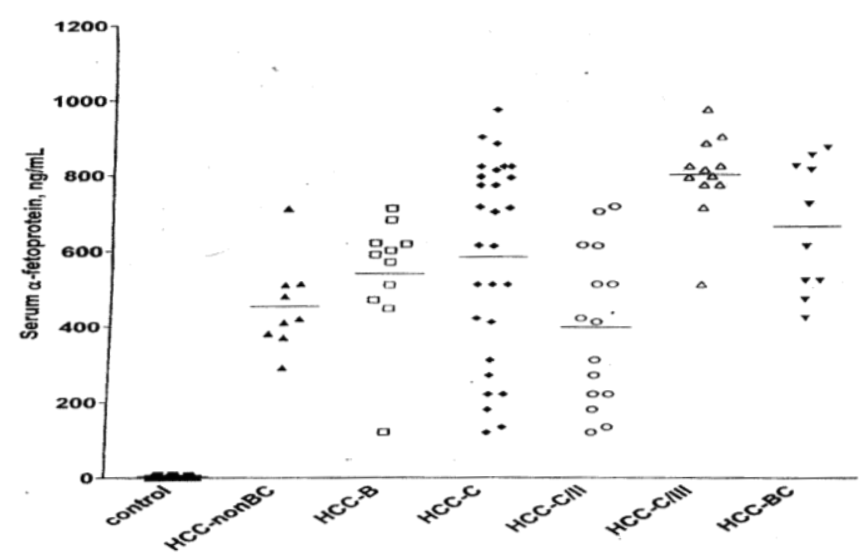

Fig. (2): Scaterogram for the individual data of $\alpha$-fetoprotein, in all studied groups.

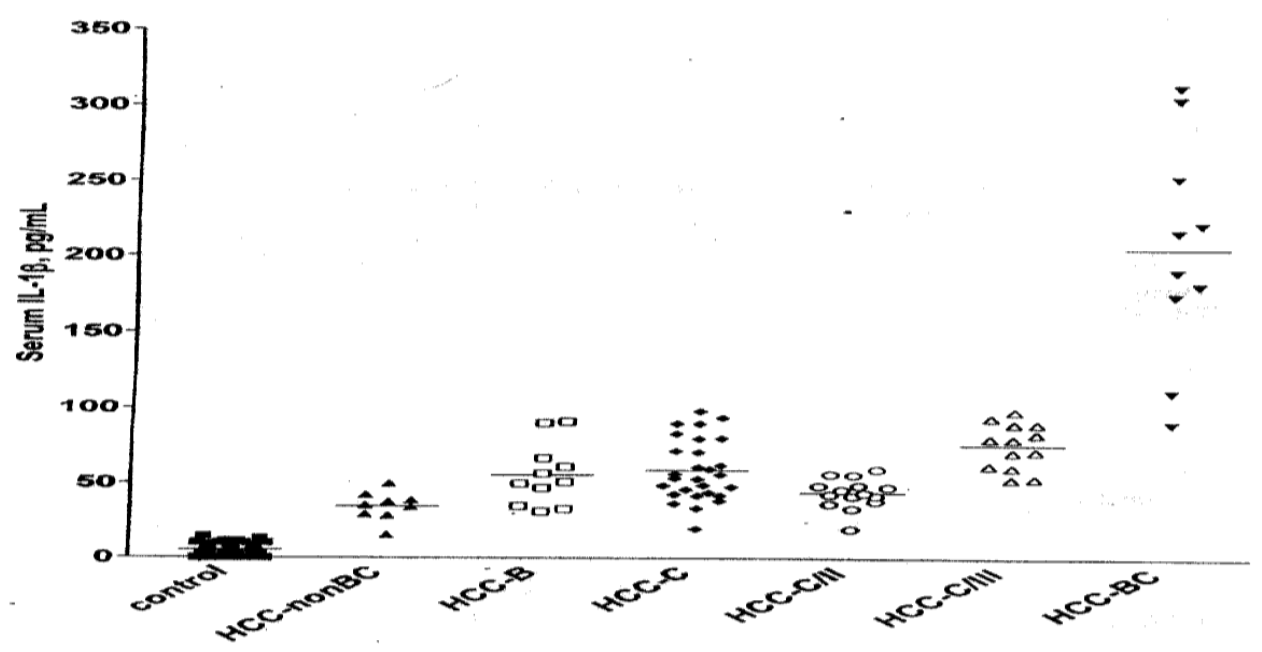

Fig. (3): Scaterogram for the individual data of IL-1B in all studied groups. 


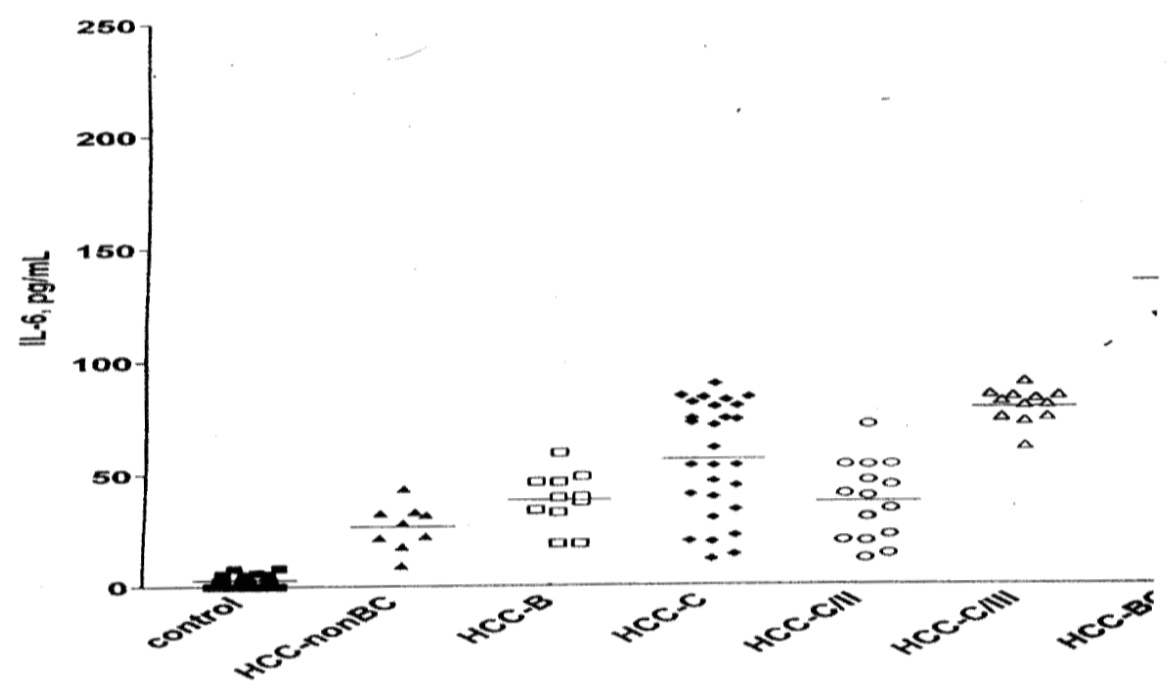

Fig. (4): Scaterogram for the individual data of serum IL-6 in all studied groups.

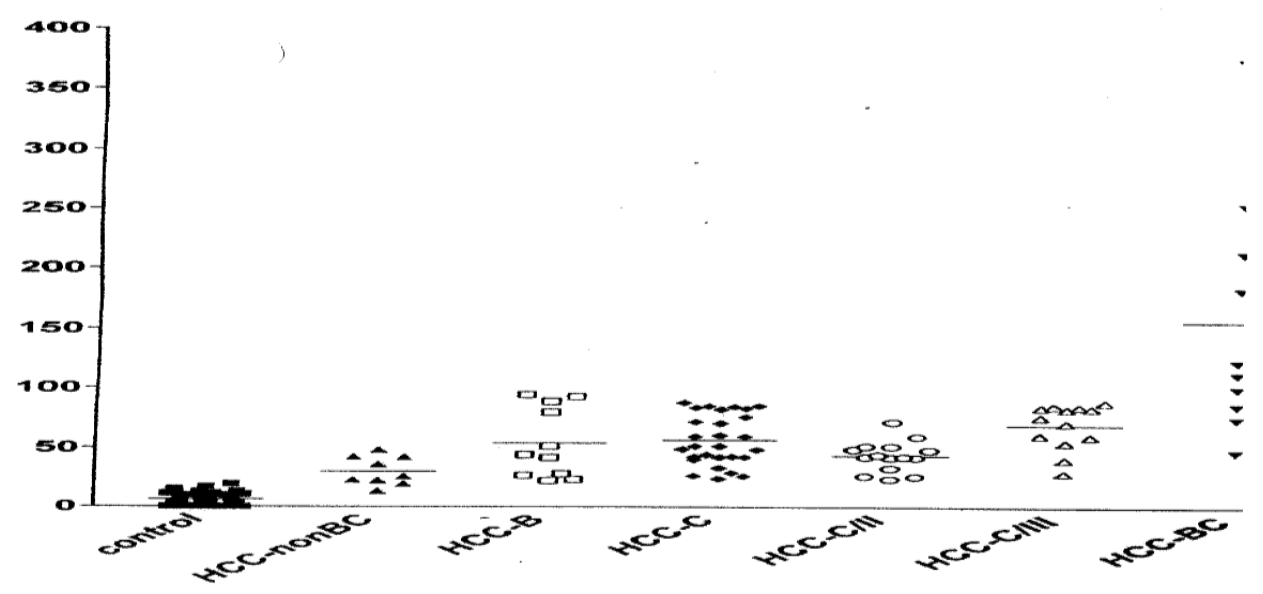

Fig. (5): Scaterogram for the individual data of serum TNF- $\alpha$ in all studied groups.

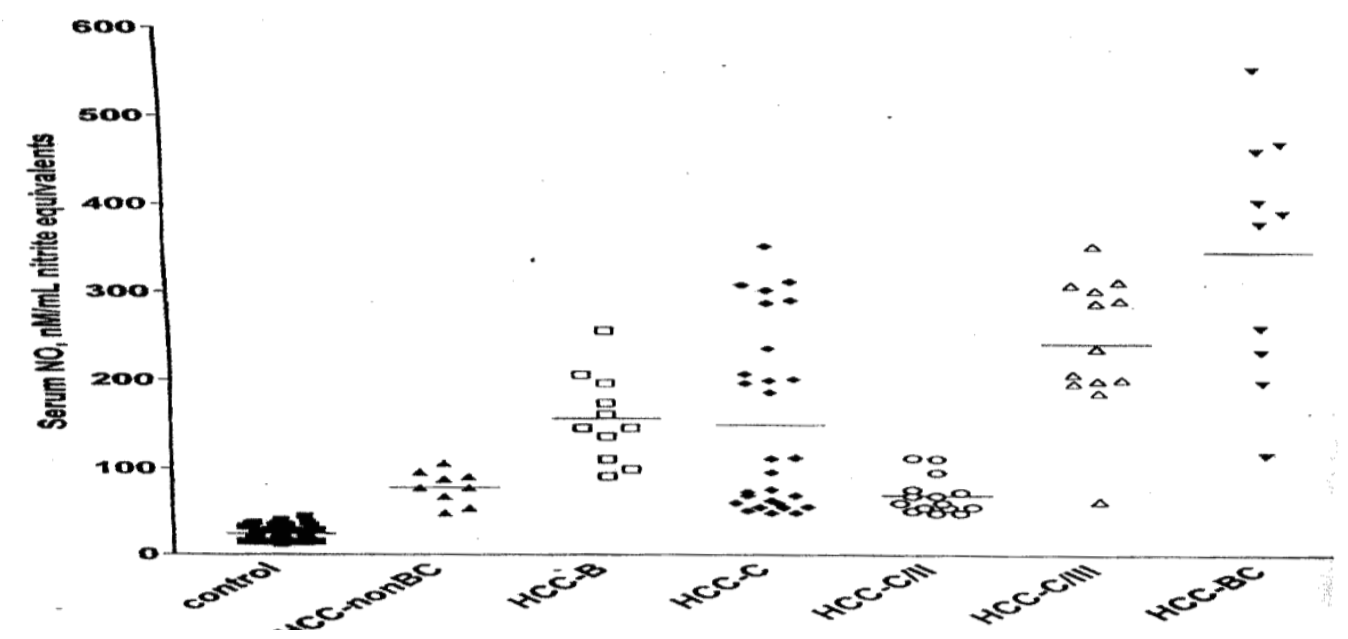

Fig. (6): Scaterogram for the individual data of serum NO in all studied groups. 


\section{Discussion}

Cytokines are synthesized and secreted in the liver mostly by Kupffer cells and play a key role in inflammatory processes and immunological responses related to liver diseases, which are initiated by hepatocytes damage. This type of signaling between different types of liver cells can produce opposing reactions; for instance, transforming growth factors beta (TGF-B) as well as interleukins (IL-1 $\beta$ ), (IL4) and (IL-6) induce fibrosis. In contrast, transforming growth factor alpha (TGF- $\alpha$ ) interleukin, one alpha (IL-1 $\alpha$ ) and interferons (IFN) are inhibitory to fibrosis. Loss of the balance between these stimul-ations seems to be responsible for activ-ation of non parenchymal cells, that result in an accumulation of extracellular matrix proteins including collagens with liver cirrhosis as a clinical effect (Flisiak, 1999).

Our results are in agreement with many authors. Loginov et al. (2001) reported high levels of TNF- $\alpha$ IL-4, IL$1 \beta$ and IL-6 in sera of patients suffering from post hepatitis $\mathrm{C}$ cirrhosis. Lee et al. (1998) reported high serum levels of IL-6 in HCC patients due to viral infection. This finding could be explained by upregulation of IL-6 production, which can eventually lead to Liver cirrhosis and HCC.

Kobsel and Ramadori (1997) reported that lysozyme synthesis and secretion were found to be augmented by IL- $1 \beta$, TNF- $\alpha$ and IL- 6 in human hepatoma cells. The authors concluded that these cytokines might have a role in modulation and production of protein molecules participate in the mechanism of carcinogenesis.

Liorent et al. (1996) reported high degree of cytokine gene expression namely transforming growth factor (TGF) interleukin 1 beta (IL-1 $\beta$ ), Interleukins $2,6,8$ and 10 as well as tomour necrosis factoralpha (TNF- $\alpha$ ) in post hepatitis $\mathrm{C}$ liver cirrhosis and cirrhotic specimens. The authors concluded that these cytokines appear to participate in the pathogenesis of the mild to sever liver damage.

Osman et al, (2000) reported that IL$1 \beta$ increased significantly in chronic hepatitis $\mathrm{C}$ than normal controls. In addition, serum concentrations of this cytokine correlated with both indices of hepatic dysfunction and parameters of hepatic inflammation. The result of present study showed higher levels of cytokines of either of Th1 origin (TNF $\alpha$ ) or of Th2 origin (IL-6). Also, IL-1 $\beta$ showed significant increase. All these increased cytokines showed highest level in Egyptian HCC patients with $\mathrm{HCV}$ and $\mathrm{HBV}$ co-infection followed by either $\mathrm{HCV}$ or $\mathrm{HBV}$ with no significant difference. HCC with no viral infection showed lowest levels of all HCC patients but still higher than normal controls.

This significant rise in all cytokines could be:

- Direct release of these cytokines from tumor cells but chronic HCV showed significant higher levels than normal (Osman et al., 2000).

- Upregulation of the genes corresponding to these cytokines.

- Host defense mechanism to guard against the disease.

- As a part of angiogenesis especially TNF$\alpha$

- As a part of antiapoptotic mechanism

- Chronic hepatitis (HBV) even HBs Ag negative, anti-HBs positive cases. This is mostly probably related to persistence of low levels of hepatic HBV DNA, which can also be isolated from tumor tissue.

The HBV encoded $x$ protein, which is known to regulate both proliferation and apoptosis (Sheu et al., 1997).

Chun - Chieh Chen et al. (2005) added that induces HCC mainly by causing dose dependent association between the number of putative high-risk genotypes in the IL- $1 \beta$, TNF $\alpha$ and HCC. Genetic variations in cytokines and DNA repair genes contributes to susceptibility to $\mathrm{HBV}$ related HCC.

The present study showed that serum levels of TEARS-MDA equivalent NO showed the highest levels in patients with $\mathrm{HCC} \mathrm{B}+\mathrm{C}$ compared to all studied groups.

Cytokines such as IL-1 $\beta$ and TNF$\alpha$ activate the vascular smooth muscle cells to produce nitric oxide. 


\section{Osman E.E. et al}

Moreover, Majamo et al. (1998) and Ahn et al. (1999) reported that hepatotropic viral infections are able to upregulate the number of gene expressions in human hepatocytes. So, the authors suggested that NO may mediate important pathogenic events in the course of chronic viral hepatitis.

Laskin et al. (2001) reported that in many models of liver damage nitric oxide and its oxidation products, such as peroxynitric, contribute to the injury process by directly damaging the tissue or by initiating additional immunologic reactions that result in damage.

Balance between protooncogene and suppressor genes is disturbed in HCC. Loginov et al. (2001) reported that protooncogene $\mathrm{C}$-fos was high in $\mathrm{HCC}$ tumor tissue.

Osman et al. (2005) had reported that that Egyptian $\mathrm{HCC}$ patients on top of $\mathrm{HCV}$ showed significant higher level of serum P53 immunohistochemical staining of tumor tissue and insulin like growth factor than negative $\mathrm{HCV}, \mathrm{HCC}$ patients and both had higher levels than normal controls. They explained these results by mutation of P53 in HCC patients especially those with positive $\mathrm{HCV}$ thus leading to sharp increase in P53 protein levels, but abolishes function of P53 in tumor cells.

So HCC may result from step use process involving different preneoplastic lesion that reflect multiple genetic events such as tumour suppressor gene inactivation and growth factors over or reexpression.

Thus increased protooncogenes, decreased or distrurbed function of suppressor genes, growth factor genes, virological factors via cytokines and oxidative stress have been implicated in hepatocarcinogenesis, which is subsequently multifactorial pathology.

The pathological study of the liver biopsies of 28 patients suffering from hepatocellular carcinoma with $\mathrm{HCV}$ infection revealed that 15 are grade II and 13 are grade III.

Patients with HCC associated with $\mathrm{HCV}$ infection showed, positive correlation between TNF- $\alpha$ and IL-1 $\beta$, IL-6, alpha fetoprotein, serum bilirubin, alkaline phosphatase and tumour grading, and between each others, while negative correlation was noted between prothrombin concentration and serum albumin in one side and IL-6, S. bilirubin, alkaline phosphatase, and tumour grading on the other side. This means that the more advanced the HCC is, the more the reflection by cytokines, the pathological grading, and effect on the synthetic function of the liver.

However, no correlations were found between the studied parameters, the ages of the patients and the tumor sizes.

Bilharziasis per se is not a documented risk factor for increasing the serum levels of any of the previous studied parameters.

Also, regarding the pathological grading of $\mathrm{HCC}$ on top of $\mathrm{HCV}$, there was no evident statistical difference between the group of patients with concomitant bilharzial infection and the group without bilharzial infection. Thus, Egyptian bilharziasis does not seem to play a role in hepatic carcinogenesis.

However, the levels of studied parameters in hepatocellular carcinoma associated with HCV infection, does not show any significant differences compared to their levels in hepatocellular carcinoma with HBV, which may be attributed to the same role of the two viruses in induction of such molecules.

\section{Conclusion}

Guarding against HCC development on top of $\mathrm{HBV}$ must require vaccination against $\mathrm{HBV}$ infection.

Also, further work must be done to reach an effective vaccine against $\mathrm{HCV}$.

Patients with HCV or HBV infection should provided with anti-inflammatory drugs or cytokine antagonists aiming to guard against HCC. Moreover, our work supports that antioxidants have a role in protection against hepatic carcinogenesis.

\section{References}

1. Ahn B, Han Bs Klim DJ and Ohshima H (1999): Immunohistochemical localization of inducible nitric oxide synthase and 3nitrotyrosine in rat liver tumours induced by $\mathrm{N}$-nitrosodiethylamine. Carcinogenesis. 20(7): 1337-44.

2. Arbuthnot $P$ and Kew $M$ (2001): Hepatitis B virus and hepatocellular carcinoma Int. J. Exp. Patho. Apr., 82(2): 77-100.

3. Fisiak R (1999): Cytokines in the pathogenesis of liver fibrosis. Przegllek., 56(9): 604-7. 
4. Kato N (2001): Molecular virology hepatitis C virus Acta . Med. 52(3): 133-59.

5. Kew M, Michael C, Yu C, Mary-Anne K, Alison C, Andrew S and John H (1997): the relative roles of hepatitis $\mathrm{B}$ and $\mathrm{C}$ viruses in the etiology of hepatocellular carcinoma in Southern African Blacks Gastroenterology., 112: 184-187.

6. Kobsel N and Ramadori G (1997): Abteilung gastroenterology and Endokrinologie, Georgy - August - Universitat Gottingen, Germany. Hepatology, 19(5): 1182-8

7. Kondoh N., Wakatsuki T., Hada A., Shuda M., Tanaka K., Arai M., and Yamamoto M. (2001): Genetics and epigenetic events in human hepatocarcinogenesis. Int. J. Oncol. 18(6): 1271-8.

8. Kuo CP, Abe Ky and Schroeder AR (2000): Superoxide enhances Interleukin 3mediated transcription of the hepatocyte inducible nitric oxide synthase gene. Gastroentrology, 188: 608-618.

9. Laskin JD, Heack DE, Gardner CR, and Laskin DL (2001): Pro-oxidant and antioxidant functions of nitric oxide in liver toxicity. Antioxid. Redox signal, 3(2): 26171.

10. Laurent-Puig P, Legoix P, Bluteau $\mathbf{O}$, Belghiti J, France D, Binot F, Monges G, thomas $G$, Bioulac-Sage $P$ and Zucmanrossi J (2001): Genetic Alterations Associated with Hepatocellular Carcinomas Define distinct Pathways of Hepatocarcinogenesis Gastroenterology: 120:1763-1773.

11. Lee Y, Park US, Choi L, Yoon SK, Park YM, Lee Yl (1998): Human interleukin 6 gene is activated by hepatitis B virus- $\mathrm{X}$ protein in human hepatoma cells elmcancer res., 4 (7): 1711-7.

12. Liorent L, Richaud-patin Y, AlcocerCastileejos N, Ruiz-Soto R, Mercado MA, Orozco El, Gamboa-Domingue ZA., and alcocervarela J (1996): J. Hepatol., 24(5): 555-63.

13. Loginov AS, Tsaregordt Seva TM, Zotine MM, Serova Tl, Lakim Chuk GN, and Fedotova TF. (2001): Interleuikns chronic viral hepatitis Ter Arkh, 73(2): 17-20.

14. Majano PL, Garcia-Monzon C, Lopezcabrera $M$, Lara-Pezzi E, Fernandezruiz E, Garcia-Iglesias C, Bortque MT, and Moreno Otero R, (1998): Inducible nitric oxide synthetase expression in chronic viral hepatitis, Evidence for a virus induced gene upregulation. J. Clin invest., 1: 101(7): 1343-52

15. Par A, Roth E, Rum GJR, Kovacs Z, Nemes I, and Mozsik G (2000): Oxidative stress and antioxidant defense in alcoholic liver disease and chronic hepatitis C. or Vheti., 141(30): 1655-9
16. Peters M, Blinn G, Jostock T, Schiramacher P, Meyer KH, Zum Biischenfelde Peter R, Galle and RoseJohn S (2000): Combined interleukin 6 and soluble interleukin 6 receptor accelerates murine liver regeneration. Gastroenterology., 119: 1163-1671.

17. Pontisso P, Gerotto $\mathbf{M}$, Benvegnu $\mathbf{L}$, Chemeiioll and Allberti A (1998): Coinfection by hepatitis B virus and hepatitis C virus Antiviral there., 3 (3): 137-42.

18. Osman EE, El-Refae Kh El $R$ and Khatab SM (2000): Interleukin-1 $\beta$ in chronic hepatitis C. scientific J. of AlAzhar Medicine Faculty., 21 (2) 11571166.

19. Osman EE, Abd Rabo SA El-Refae Kh E, El-Gendy SM, Hassanen HM, Zaki IM, and Hassan MA (2005): Insulin Like growth factor-1 and p53 in Egyptian patients with Hepatocellular carcinoma Al. Azhar University and National Cancer Institue. Egg. J of Bioch. And Molecular Biology (EJBMB) 23: 501-518.

20. Satoh K (1978): Serum lipid peroxidation in cerebrovasocular disorders determined by a new colorimetric method Clin. Chem. Acta., 90: 37.

21. Sadamori H, Yagi T, Kanaoka Y, Morimoto Y, Inagadki M, Ishikawa T, Mastukawa H, Masuda EL, Iwagaki H, and Tanaka $\mathbf{N}$ (2002): The analysis of the usefulness of laparoscopic microwave coagulation therapy for hepatocellular carcinoma in patients with poor hepatic reserve by serial measurements of IL-6, cytokine antagonists and C-reactive protein. Surg. Endosc., 17(3): 510-4.

22. Schlenker T, Andrew $\mathbf{P}$, Ferancha $\mathbf{K}$, Schwake L, Stremmel W, Richard M, Gregory $J$ and Fitz (2000): Functional interactions between oxidative stress, membrane Na permeability and cell volume in rat hepatoma cells, gastroenterology, 118: 395-403.

23. Umeda T and Hino O (2002): Molecular aspects of human hepatocarcinogenesis mediated by inflammation from hypercarcinogenic state to normo-or hypocarcinogenic state. Onclology, 62 (1): 38-42.

24. Van Bezooiyen RL, Que I, Ederveen AGH, Kloosterboer HJ, Papapoulous SE and Lowik CUGM (1998): Plasma nitrate + nitrate levels are regulated by ovarian steroids but do not correlate with trabeculae bone mineral density in rats. J. Endocrinal, 159: 27.

25. Vinogradous MA (2001): Synthesis of nitric oxide in patients with viral hepatitis. Antibiot. Khimoter; 46(4): 26-8. 


\section{العوامل المؤدية الى انتشار سرطان الكبد فى مصر الإصابة بفيروس بي

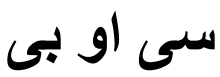

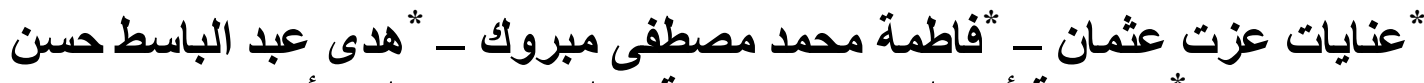

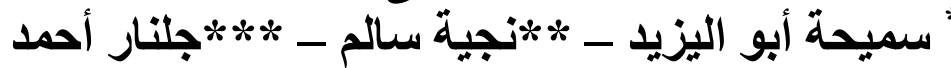

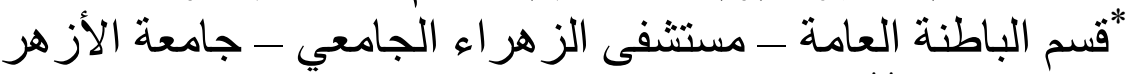

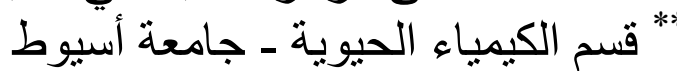

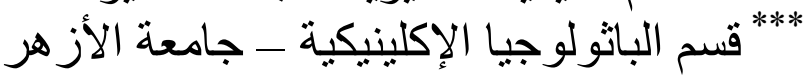

يعتبر سرطان الكبد من اكثر الأورام السرطانية شيوعا فى البلاد النامية كما تعثبر

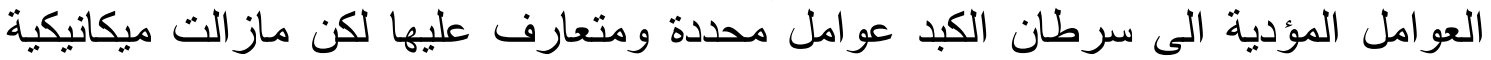

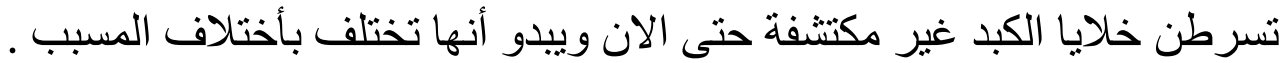

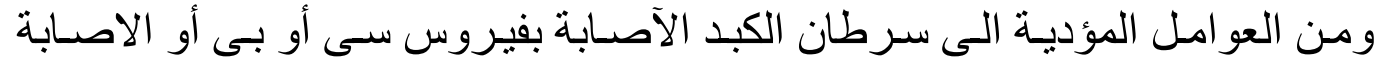

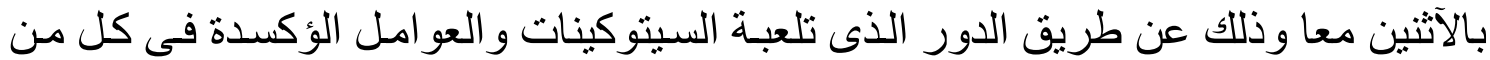

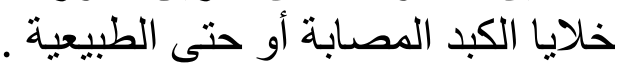

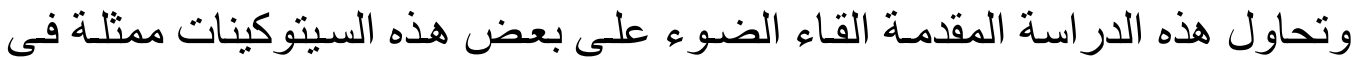

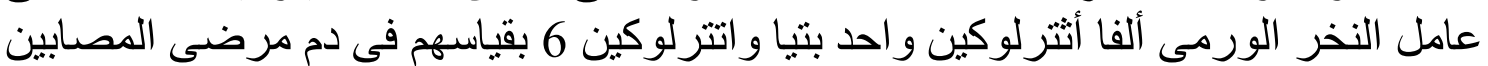

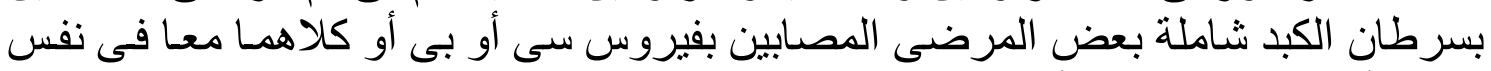

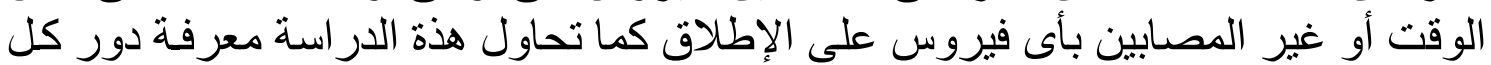

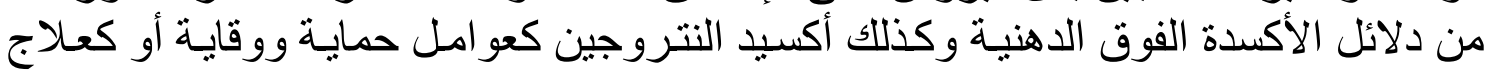

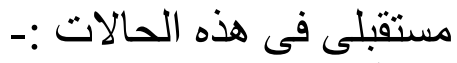
وقد أجريت هذة الدر اسلة على 98 مريضا يعانون من الاصابة بسرطان الكبد مقسمون الى

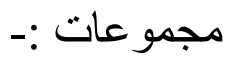

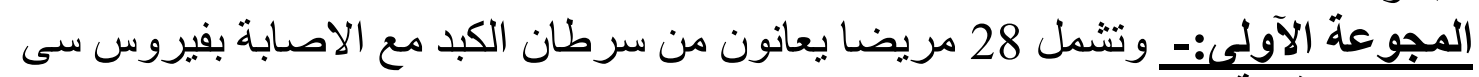

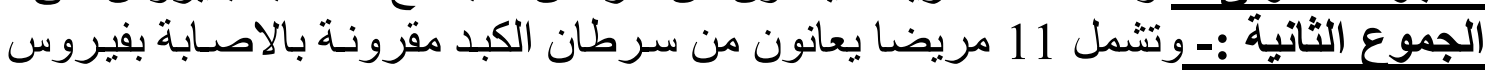

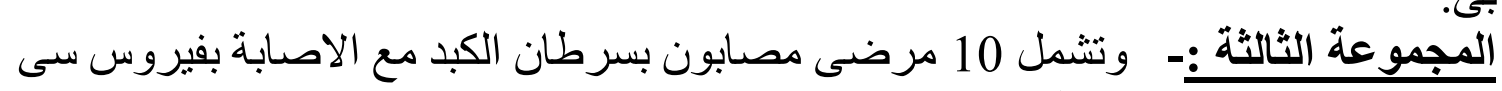

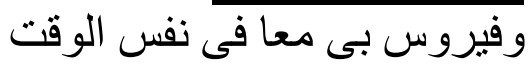

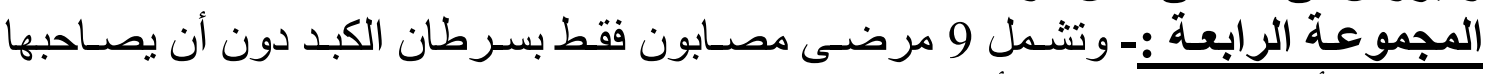

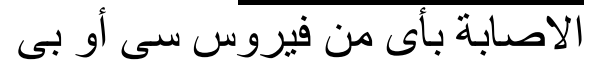

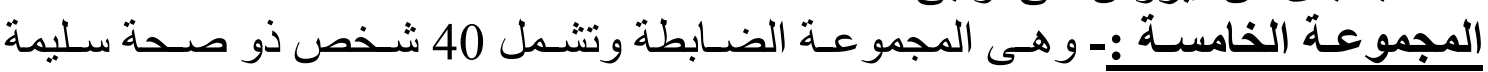

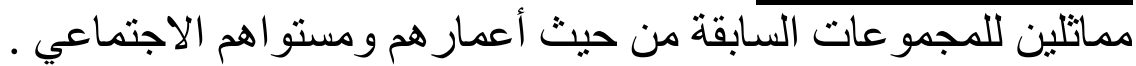

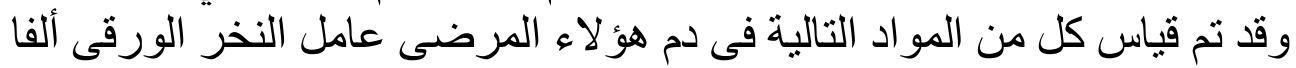

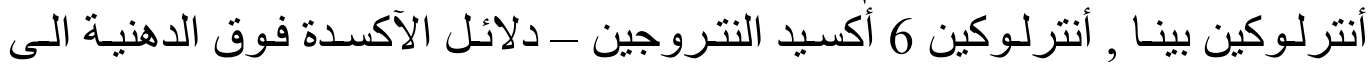

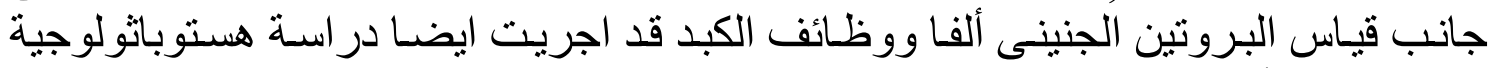

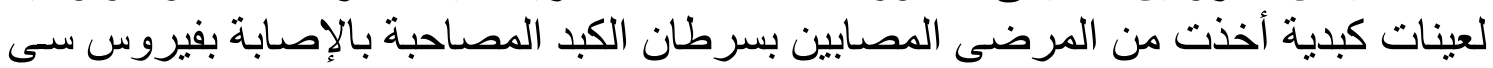

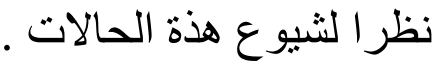
ولقد دلت نتائج هذه الدراسة على زيادة كل من عامل النخر الورمى ألفا , أنترلوكين

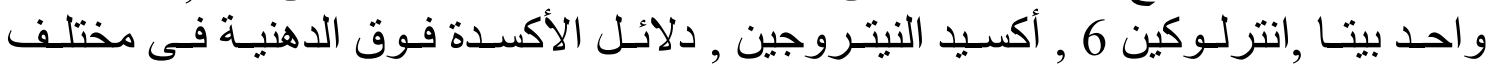




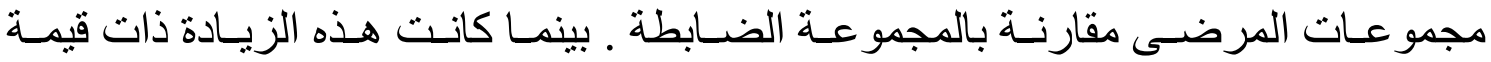

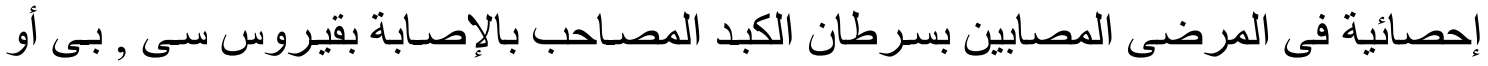

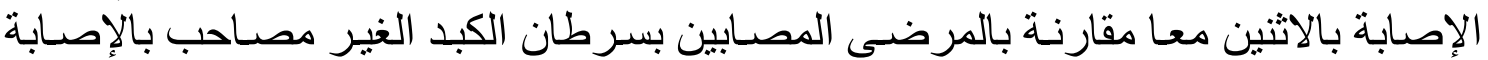

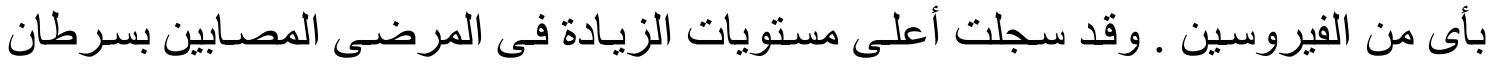

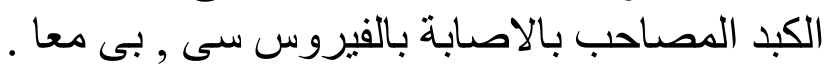
ولقد أوضحت النتائج أيضا وجود علاقات إحصائية ايجابية بين كل من عامل الته النخر الورمى و أنترلوكين و احد بيتا , اتتروكين 6 , أكسيد النتروجين وكل من البروتين الجينى ألفا

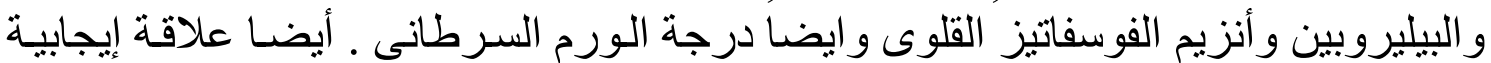

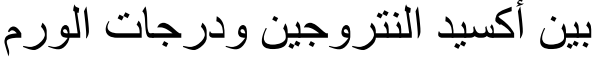

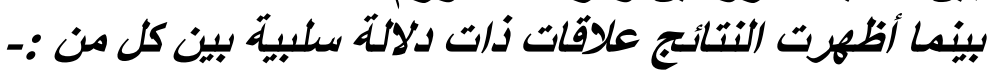

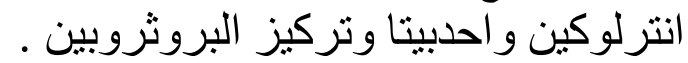
البروتين الجينيتى ألفاوكل من تركيز البروثروبين بروبن وتروكيز البروتين الكلى بالدم .

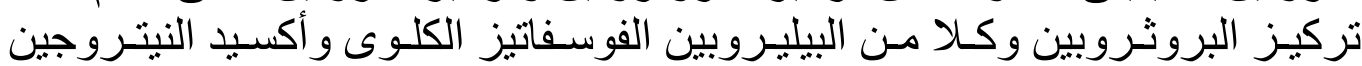$$
\text { ودرجات الورم. أكبيد النزوجين وكل من }
$$
ودرجات الورم .

أكسيد النتروجين وكل من الالبومين و البروتين الكلى .

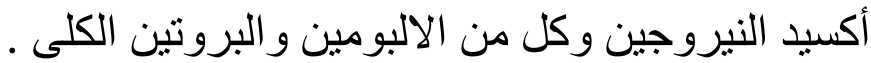

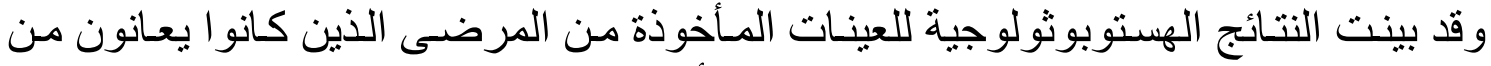

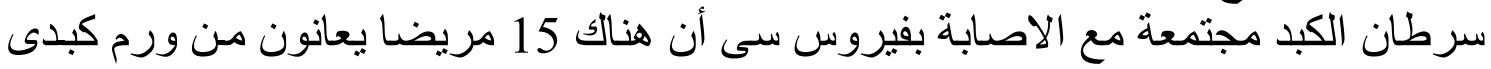

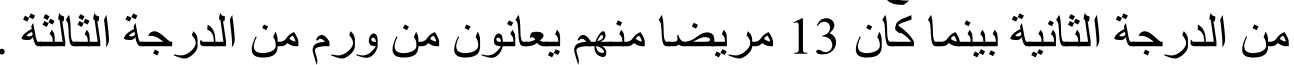

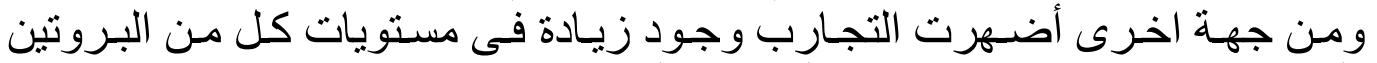

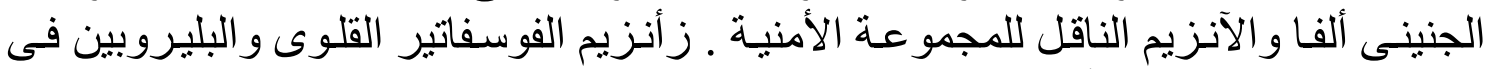

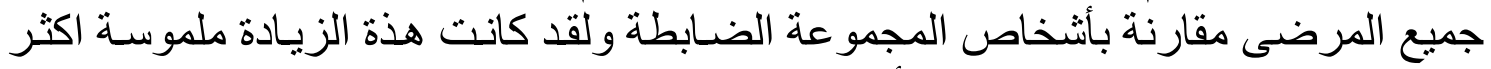

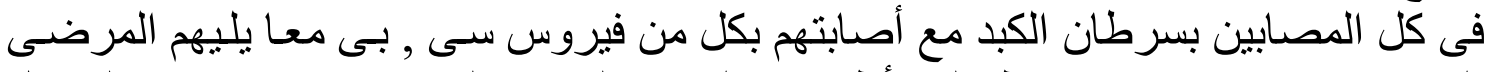

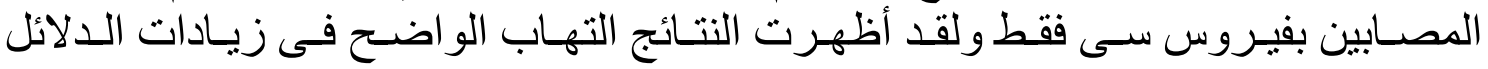

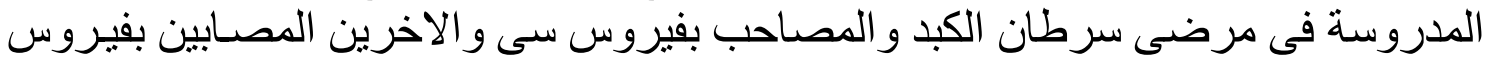

بى وهذا يعزى الى قدرة كل من الفيروس على على تخليق هذة الجزيئات بنفس القدرة

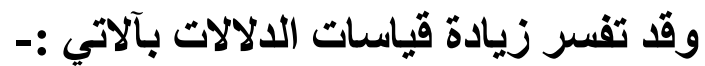

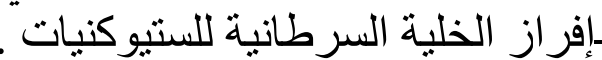

تتبية للجينات المسئولة عن تكوين هذة الستيلوكنيات كدفاع من الخلية ضد هذاتية المرض

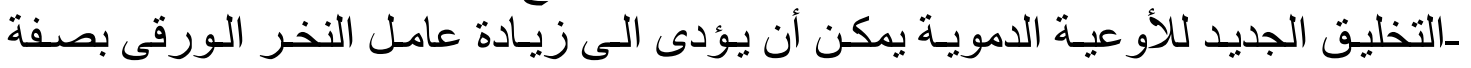

$$
\text { ـأيضا نتيجة لدور الموت المبرمج للخلية }
$$

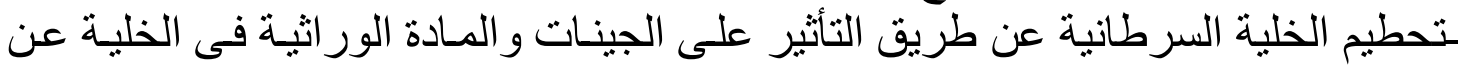
طريق نر اكم كل من شقوق الاكسجين والاكاسيد فوق الدهنية و أكسيد النتروجين و التى تحدث

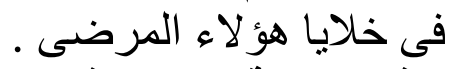

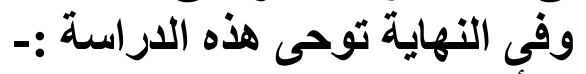

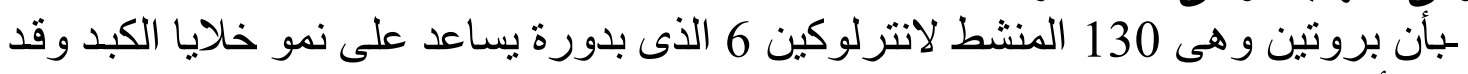

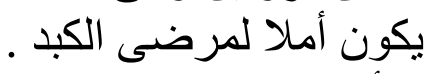
ـأمكانية استخدام عامل النخر الورقى الفا كعلاج للخلايا السرطانية بالكبد .

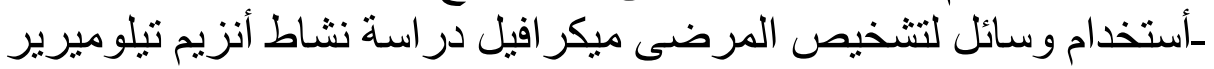




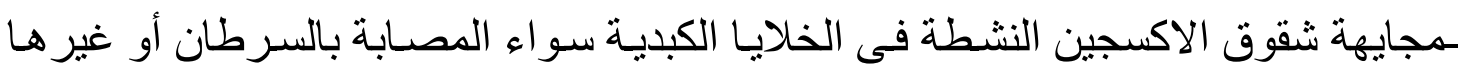

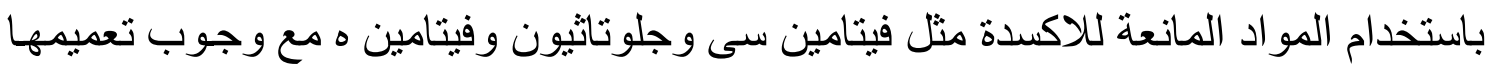
- جعل التطعيم ضد فيروس بـى اجباريا .

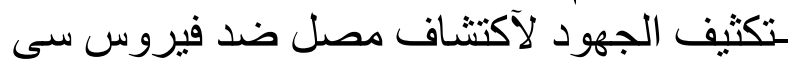
ـالادوية التى لها علاقة بالموت المباف المبرمج للخلية و التكوين الجديد للآوعية الدمويـة قد يكون

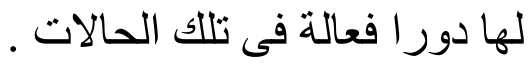

